\title{
Effectiveness of High Energy Efficiency to Minimize Energy Consumption for Residential Buildings in Egypt \\ Gehad Mohamed Abdelsalam ${ }^{1}$, Zeinab Mohamed EL Razzaz ${ }^{2}$, Fatma Elnekhaily ${ }^{3}$
}

\begin{abstract}
A b s t r a c t
The effects of global warming and climate change have become a critical issue in our world where the average air temperature rises to $2^{\circ} \mathrm{C}$ that leads to sea-level rise, seasonal disturbances storms, floods, and massive fires. [1]

Increasing energy demand during the cooling period has become an essential issue in Egypt. Solutions can be applied to develop the building envelope for existing buildings by implementing a different technique that can enhance energy performance and improve indoor thermal comfort. The roof is the one of building envelope components which can reduce energy consumption and enhance indoor thermal comfort in buildings.

The scope of this paper deals with evaluating the energy performance of residential buildings using different roof techniques: cool roof, green roof, isolated roof and integrated roof with Phase Change Materials (PCM) in Egypt that can lead to different solution of roof to achieve ideal energy performances .The assessment is carried out by using the Design Builder Software which can be able to calculate the monthly energy consumption.
\end{abstract}

Keywords: Energy Efficiency-Cool roof-Green roof- Phase Change Material (PCM)-Roof insulation- Thermal Comfort.

\section{Introduction}

Globally the building sector is responsible for $40 \%$ of overall energy consumption [2]; while in Egypt, the building sector is responsible for $62 \%$ of the total electricity consumption, $26 \%$ of the total energy consumption and $70 \%$ of $\mathrm{CO} 2$ emissions [3].

So Egypt today faces environmental and energy challenges due to the increase of urbanization and population that causes an increase in energy demand specially in residential sector due to the increase of air conditioning units; Air

\footnotetext{
${ }^{1}$ Teacher assistant at Modern Academy for Engineering and Technology (Maadi)

${ }^{2}$ Vice dean for students affairs ,faculty of Engineering Matarya, Helwan University

${ }^{3}$ Lecturer, Architectural Dept, faculty of Engineering Matarya, Helwan University
} 
conditioning in residential buildings in Egypt consumes about 56\% of total energy per annum [4]

Thus Egypt still underestimates the importance of activating building codes to enhance building performance. The construction developers in Egypt use the minimum expenses to construct a building and ignore any performance codes available. In return, a building consumes more energy consumption and provides an uncomfortable indoor thermal comfort for the occupants. [5] Therefore, any solutions towards improving the energy efficiency in building sector plays an important role in reversing the negative impact on environmental and energy demand.

This paper examines the advantages of the reducing energy consumption by implementing different roof techniques (cool, Phase Change Material (PCM), isolated and green roofs) on an existing residential building in Egypt using Design builder Software.

\section{Methodology}

The research implements different roof techniques (Cool Roofs, Integrated Roofs with Phase Chang Material (PCM), Isolated Roofs and Green Roofs) for existing residential buildings (base case) to enhance the energy performance of the building and decrease the amount of energy needed to minimum.

Using energy simulation program (Design Builder) to investigate the amount of energy saved by the retrofitting solutions for the typical residential buildings comparing to the current Situation to achieve the aim of the study presented in this research.

Analysis of the current situation of building envelop for existing residential building in Cairo according to energy consumption and comfort by simulation program (DesignBuilder Software)

applicant different roof technique (cool, Phase Chang Material (PCM), isolated and green roofs)on the roof for existing residential building

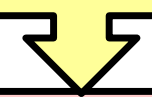

Data analysis procedure: analytical procedure to evaluate the year-round benefits and penalties that are implementation and Analysis of the results and recomented the optimal alternative

Figure 1Research Suggested Methodology source: the researchers 


\section{Research problem}

In Egypt the function of roofs is limited to protect the upper floors from rainfall in winter and sunlight all throughout the year. So it is not efficient in terms of building energy consumption since it has not suitable heat insulation and other roofs techniques .The temperature in the upper floors is higher than that in the lower ones, this is due to be subjected to direct sun rays all day long, especially in summer periods. Hence, it is necessary to improve existing roof by using different roof techniques (cool, Phase Chang Material (PCM), isolated and green roofs) on residential building.

\section{Building description}

The building chosen is a typical residential building in Egypt. The building is consisting of 4 stories with two apartments per floor the area of apartment is $140 \mathrm{~m} 2$, the total area of the building is $400 \mathrm{~m} 2$ and its height is $12 \mathrm{~m}$ with a flat roof. The building has one stair. the study focuses on apartment under the roof. The floor plan and model for the case study as shown in figures5.

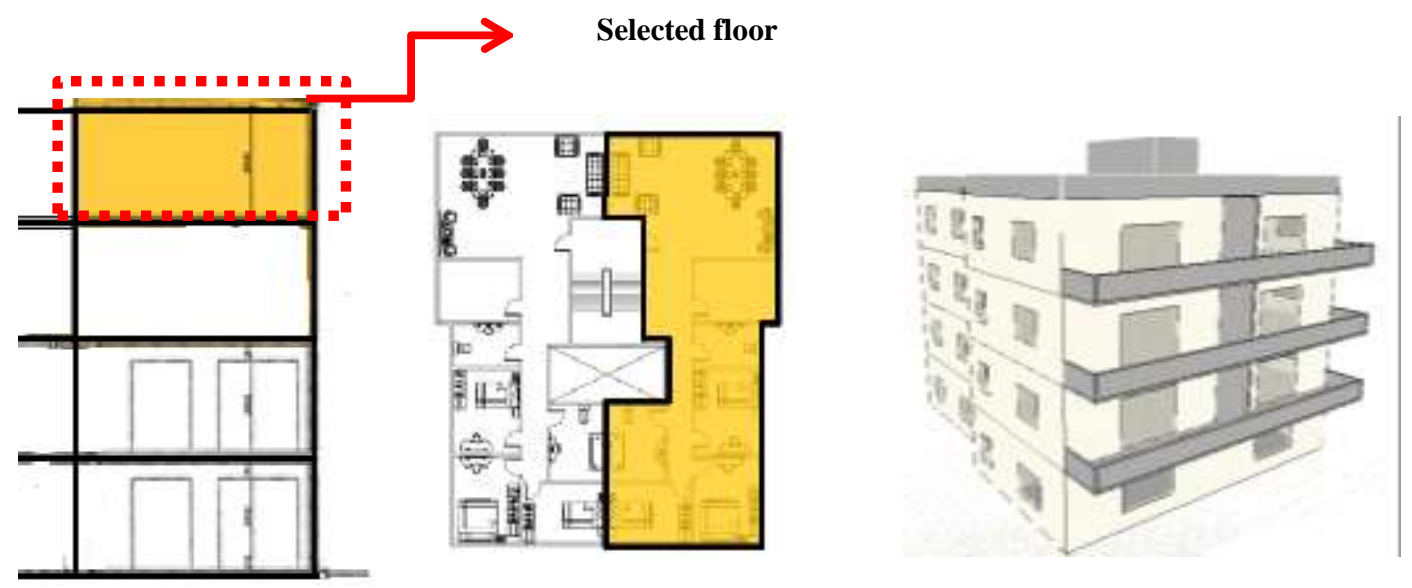

Figure 5 the typical floor plan and $3 \mathrm{~d}$ model for the selected case study source: the researchers

\subsection{Building Performance Simulation}

Design Builder is a whole building simulation software tool. It uses energy plus's open source code to simulate the indoor microclimate and energy use. The program enables users to model full detailed buildings. Modeling interface is userfriendly and a descriptive content is provided to help users. Users model building with full description to every building system used; from schedules, construction materials to lighting, HVAC system and openings percentages. 


\subsubsection{Construction Settings}

The construction materials used in this case study are conventional construction materials the specifications for construction materials used in the simulation are:

- The exterior walls consist of $12 \mathrm{~cm}$ red brick with an interior finish of thermal plaster $2.5 \mathrm{~cm}$. (U-value $=\mathbf{2 . 1 9} \mathrm{W} / \mathrm{m} 2 . \mathrm{K}$ )

- Internal partitions are made of $12 \mathrm{~cm}$ thick red brick in addition to $4 \mathrm{~cm}$ thickness of cement plaster. (U-value $=2.4 \mathrm{~W} / \mathrm{m} 2 . \mathrm{K}$ )

- Floors are consist of $12 \mathrm{~cm}$ Reinforced concert with $10 \mathrm{~cm}$ finishing thickness made of sand, mortar and ceramic tiles $(\mathrm{U}$-value $=2.3 \mathrm{~W} / \mathrm{m} 2 . \mathrm{K})$

- Roof is made from concrete of $12 \mathrm{~cm}$ thick $.2 \mathrm{~cm}$ water proofing and 10 $\mathrm{cm}$ sand, mortar and Mosaic tiles. Roof without insulation (U-value= $2.65 \mathrm{~W} / \mathrm{m} 2 . \mathrm{K})$

\subsubsection{Glazing type and lighting}

There are four glazing types usually used in Egypt stated in (EREC) as shown in Table 1. Windows used in simulations are made of aluminum frames and $6 \mathrm{~mm}$ clear single glazing. The window to wall ratio (WWR) is $15 \%$. On the other hand, each room has artificial lighting 2 lamps with $1200 \mathrm{~mm}$.

Table 1 the Glazing type categories commonly used in Egypt

\begin{tabular}{|l|l|l|l|l|}
\hline Name & category & $\begin{array}{l}\text { Solar heat gain } \\
\text { coeficient } \\
\text { (SHGC) }\end{array}$ & $\begin{array}{l}\text { Light } \\
\text { transmission } \\
\text { (LT) }\end{array}$ & $\begin{array}{l}\text { U-value } \\
\text { W/m2 } \\
\text {.K }\end{array}$ \\
\hline $\begin{array}{l}\text { Clear 6 mm } \\
\text { (stainless steel cover 8\%) }\end{array}$ & $\begin{array}{l}\text { Single } \\
\text { reflective }\end{array}$ & 0.71 & 0.18 & 0.65 \\
\hline $\begin{array}{l}\text { Clear 3.2mm } \\
\text { Transparent/Transparent } \\
\text { (6.0mmair) }\end{array}$ & $\begin{array}{l}\text { Double } \\
\text { reflective }\end{array}$ & 0.66 & 0.06 & 5.36 \\
\hline $\begin{array}{l}\text { Clear reflective 6.4mm } \\
\text { Transparent (stainless steel } \\
\text { cover 8\%)/ transparent- } \\
\text { (6.0mmair) }\end{array}$ & $\begin{array}{l}\text { Double } \\
\text { reflective }\end{array}$ & 013 & 0.59 & 3.71 \\
\hline
\end{tabular}

\subsubsection{Activities and schedule}

Schedules are used; in conjunction with the cooling and heating set points. Concerning air temperature control the cooling set point temperature is $24^{\circ} \mathrm{C}$ and a ventilation rate is 0.5 air changes per hour. In DesignBuilder define certain activities for example lighting, equipment, occupancy times and HVAC operation. Energy consumption schedules are used for the simulations defined activity 
template based on the common lifestyle for the residents of Egypt work hours and holidays. Table 2 shows the occupancy rate and occupancy schedule [36].

Table 2 parameters, occupancy and window schdules.

\begin{tabular}{|l|l|}
\hline Parameter & Description \\
\hline Occupancy rate & 0.25 person/m2 \\
\hline Activity factor & 0.9 \\
\hline Clothing value & Winter Clo: 0.9 and Summer Clo: 0.5 \\
\hline
\end{tabular}

\subsection{Roof technologies}

Cool roofs are considered passive technique used for energy savings; they are used as coating or tiles for the roof of the building. This technologies are based on a high solar reflectance and a high thermal emissivity. [6]

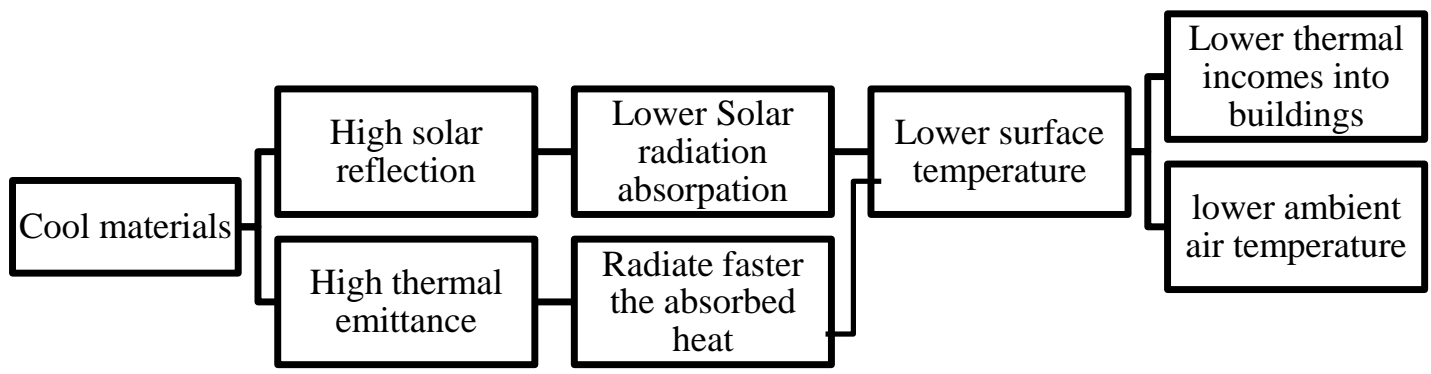

Figure 2 the thermal prosperities of cool material Source: the researchers

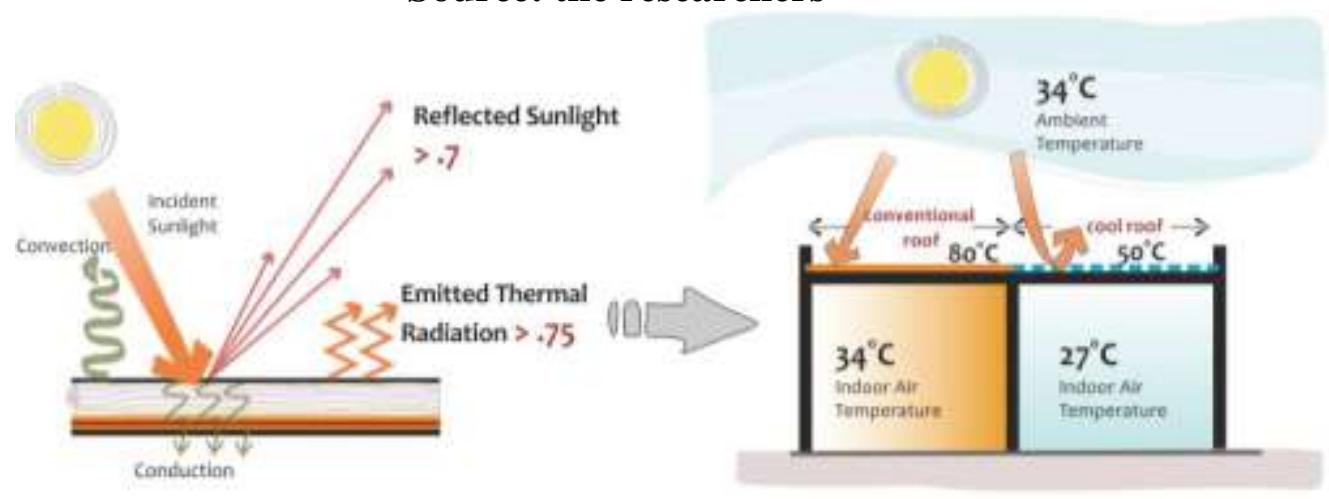

Figure 3 the performance of cool roof Source: https://nzeb.in/knowledgecentre/passive-design/cool-roofs/

Most traditional roofs reflect no more than $20 \%$ of incoming sunlight while a cool roof reflects from $60 \%$ to $85 \%$ of sunlight. Cool materials are able to maintain a temperature differential of 6-8 $\mathrm{C}$ between ambient and indoor air temperature due to high thermal emittance and solar reflectance [7]. 
Numerous studies have been carried out to evaluate the energy consumption and indoor thermal comfort of buildings with cool roofs. Cool roofs have the advantage of decreasing the cooling energy consumption during summer period and the disadvantage of using cool roofs is slightly increasing in heating energy consumption during the winter period because of solar reflectance of cool materials [8-12]. Different case studies have been undergone studying internal surface temperature, indoor air temperature, and indoor relative humidity. Every case study has a base case before and after application of cool materials to firmly point out the potentiality of a cool roof and its effect on thermal comfort [13-14].

Green roof is a passive cooling technique that reduces the received solar radiation from reaching inside the building. So Adding vegetation layers to any building is proved that it is an effective strategy with numerous benefits on energy saving, water management and reduce urban heat island effect. Thermal efficiency of the green roofs depending on the climate data and building envelop properties as Ascione shows in his study [15]. Many studies have been conducted over the past decade investigating the impact of vegetation when it applied on roofs of the buildings on reducing energy consumption [16-20], while other researchers have proved that the green roofs improve thermal comfort and mitigate the urban heat island measures [21-24].

A phase change material (PCM) is one of the techniques that reduce energy demand in buildings it can release and absorb huge amounts of energy through phase transitions with slight temperature changes. A lot of researches studied the effect of integrated of PCM with roof of the building on reducing energy consumption and improving thermal comfort [25]
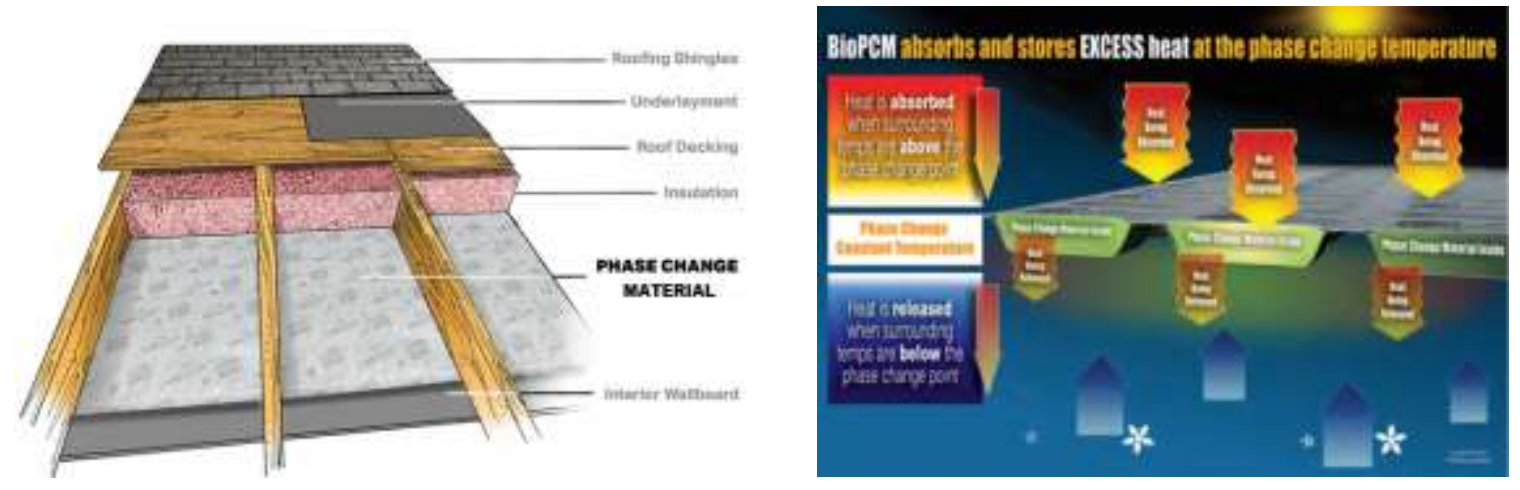

Figure 4 Operating Principle of BioPCM source: phasechangeenergy.com 
The application of PCM could increase the thermal mass of the building thus improve indoor temperature around $4 \mathrm{C}$ in summer [26]. In another study it found that addition of PCM layer with $0.15 \mathrm{~cm}$ thick to roof reduce indoor temperature $1.7 \mathrm{c}$ in summer [27]. Numerous studies have been carried out to evaluate reducing the energy consumption and thermal comfort improvement in buildings if application PCMs on roof [28-31].

According to many researches, the thermal insulation of building envelope is one of the most important strategies for reducing heat loss, energy consumption and improving the indoor thermal comfort [32-33]. It is the cheapest passive strategy in hot climates [35].

This study focused on evaluating the energy performance of residential buildings when existing flat roofs are integrated with different roof techniques. The following describes the selected roof solutions:

Table3 Describes roof layer properties for the simulation

\begin{tabular}{|c|c|c|c|c|}
\hline Base case & cool roof & GR Green roof & Isolated roof & PCM roof \\
\hline $\begin{array}{l}\mathrm{U} \text {-value }= \\
2.65 \mathrm{~W} / \mathrm{m} 2 . \mathrm{K})\end{array}$ & $\begin{array}{lr}\text { solar } & \text { reflectance } \\
0.8 & \text { thermal } \\
\text { emittance } & 0.9 . \\
\text { Specific } & \text { Heat in } \\
(\mathrm{J} / \mathrm{kg}-\mathrm{K})=1700\end{array}$ & $\begin{array}{l}\text { Thermal } \\
\text { Conductivity }=0 \text {. } \\
3 \\
\text { Specific Heat in } \\
(\mathrm{J} / \mathrm{kg}-\mathrm{K})=1000 \\
\text { Height of plants } \\
\text { in }(\mathrm{m})=0.3 \\
\text { Emissivity }=0.9\end{array}$ & $\begin{array}{l}\text { Thermal } \\
\text { Conductivity }= \\
0.032 \\
\mathbf{U}-\mathbf{v a l u e}=\mathbf{0 . 2 3}\end{array}$ & $\begin{array}{l}\text { Thermal } \\
\text { Conductivity = } \\
\text { 0.20 } \\
\text { Latent heat } \\
(\mathbf{k J} / \mathbf{k g})=\mathbf{2 1 9} \\
\text { Specific heat } \\
(\text { J/kg k)= } 1970 \\
\text { Melting point } \\
(\circ \mathrm{C})=\mathbf{2 9}\end{array}$ \\
\hline \begin{tabular}{|l|} 
Interior \\
plastar Board \\
Reinforced comere \\
Water Proofing \\
sloped Concrete \\
Sand Mortar and \\
roof tiles
\end{tabular} & $\begin{array}{l}\text { Interior } \\
\text { - olastar Board } \\
\text { Reinforced concrete } \\
\text { Rand, Mortar } \\
\text { and roof tiles } \\
\text { cool material layer }\end{array}$ & 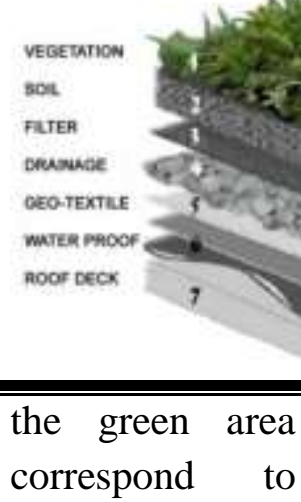 & $\begin{array}{l}\text { Can replace } \\
\text { existing floor } \\
\text { finish because } \\
\text { it is found in } \\
\text { the form of } \\
\text { tiles with final } \\
\text { finishing }\end{array}$ & 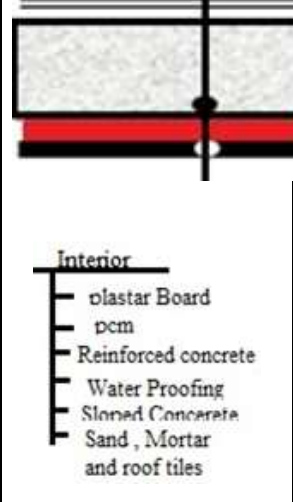 \\
\hline
\end{tabular}




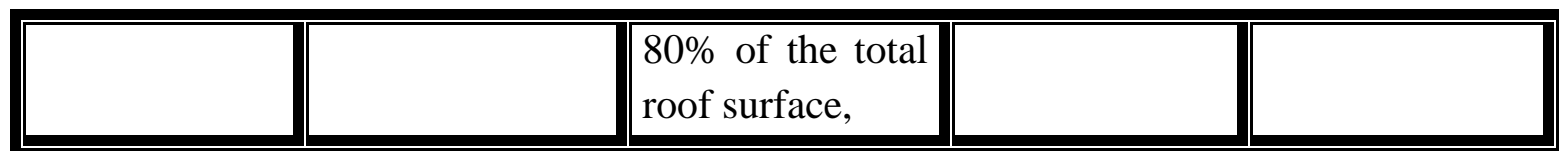

\section{Results and Discussion}

\subsection{Building energy comparison for the different roofing techniques}

In order to validate the simulation results, a comparison between actual monthly electricity consumption for the selected apartment $(140 \mathrm{~m} 2$ on the third floor of a residential building located in Cairo $6^{\text {th }}$ October city, and its duplicate simulated with DesignBuilder. Electricity utility bills for the whole year 2018 have been collected. Results of the comparison shown in Figure (6) there is very close consumption rates for Electricity between the actual building and one simulated in the software. Differences around $11 \%$ are acceptable. These differences are due to the dynamics of the human factor.

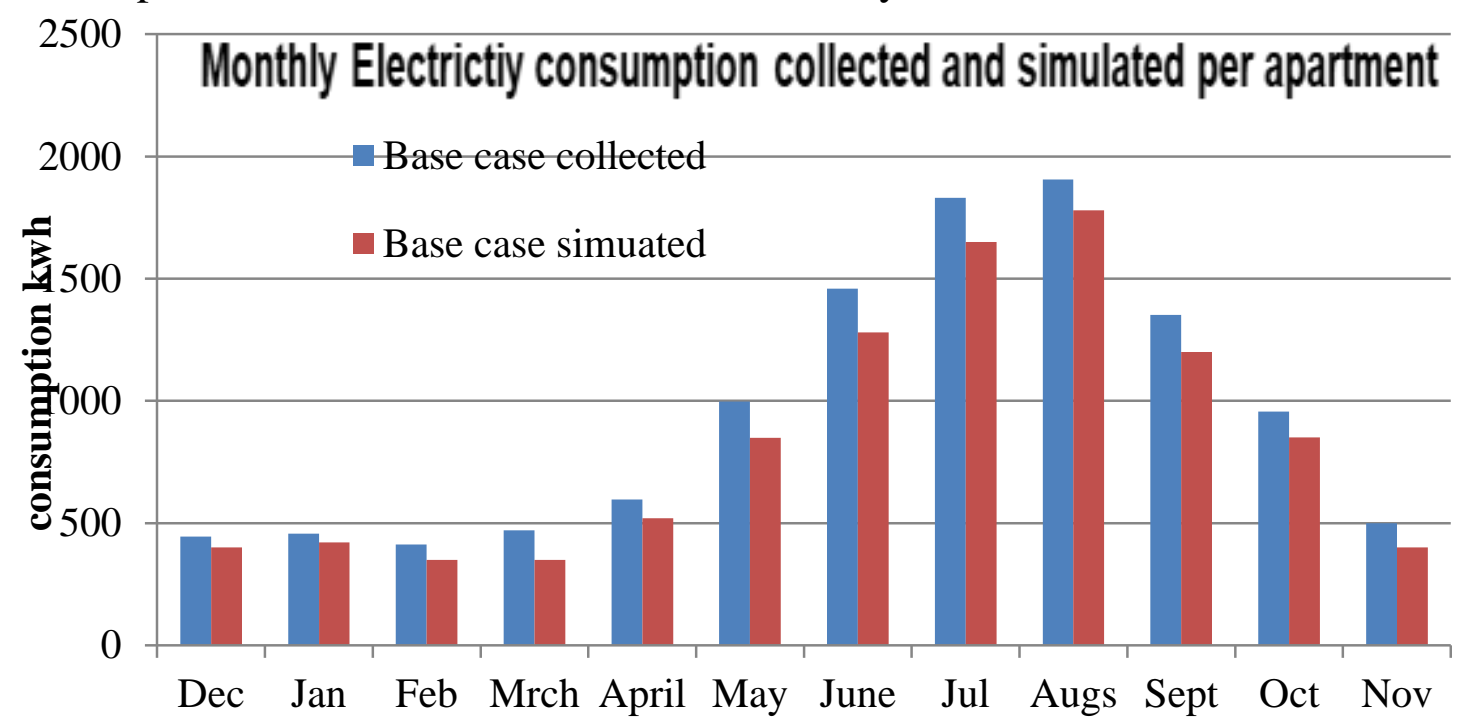

Figure6 monthly l electricity consumption for actual apartment compared with simulated

It is observed in Figure (7) that cooling energy consumption increases in May, June, July, and August due to the increased solar radiation in these months. The results of this study indicate that incorporating a PCM with an appropriate melting temperature into roof is the most effective technique; it has more cooling energy saving per annum than the rest of the roof With Insulation, green Roof and cool roof during the cooling periods.

In general cooling accounts $40 \%$ of annual electricity usage. The total yearly cooling energy consumed by the base case model around $25048.3 \mathrm{kWh}$ per annum, while roofs with insulation, Green Roof, cool roof and Roof with phase change 
material have reduced the total annual energy consumption of $21168.67 \mathrm{kWh}$, $19733.28 \mathrm{kWh}, 20003 \mathrm{kWh}$ and $17176 \mathrm{kWh}$. thus, reduction of $15.4 \%, 21.21 \%$, $20.14 \%$ and $31.4 \%$ of the total annual cooling energy consumption are provided respectively comparing with base case. Table (4)summarizes the results of the simulated cooling energy consumption for the Base case , roof with insulation, Green roof, cool roof, and roof with phase change material.

Table 4 the results of the simulated cooling energy performance for different roof technique and base case

\begin{tabular}{|l|l|l|}
\hline \multicolumn{1}{|c|}{ Roof type } & $\begin{array}{l}\text { Annual cooling } \\
\text { consumption }\end{array}$ & Saving\% \\
\hline Conventional roof (Base case) & 25048.3 & Base case \\
\hline Roof With Insulation & 21168.67 & $15.4 \%$ \\
\hline Green Roof & 19733.28 & $21.21 \%$ \\
\hline cool roof & 20003 & $20.14 \%$ \\
\hline Roof with phase change material & 17176 & $31.4 \%$ \\
\hline
\end{tabular}

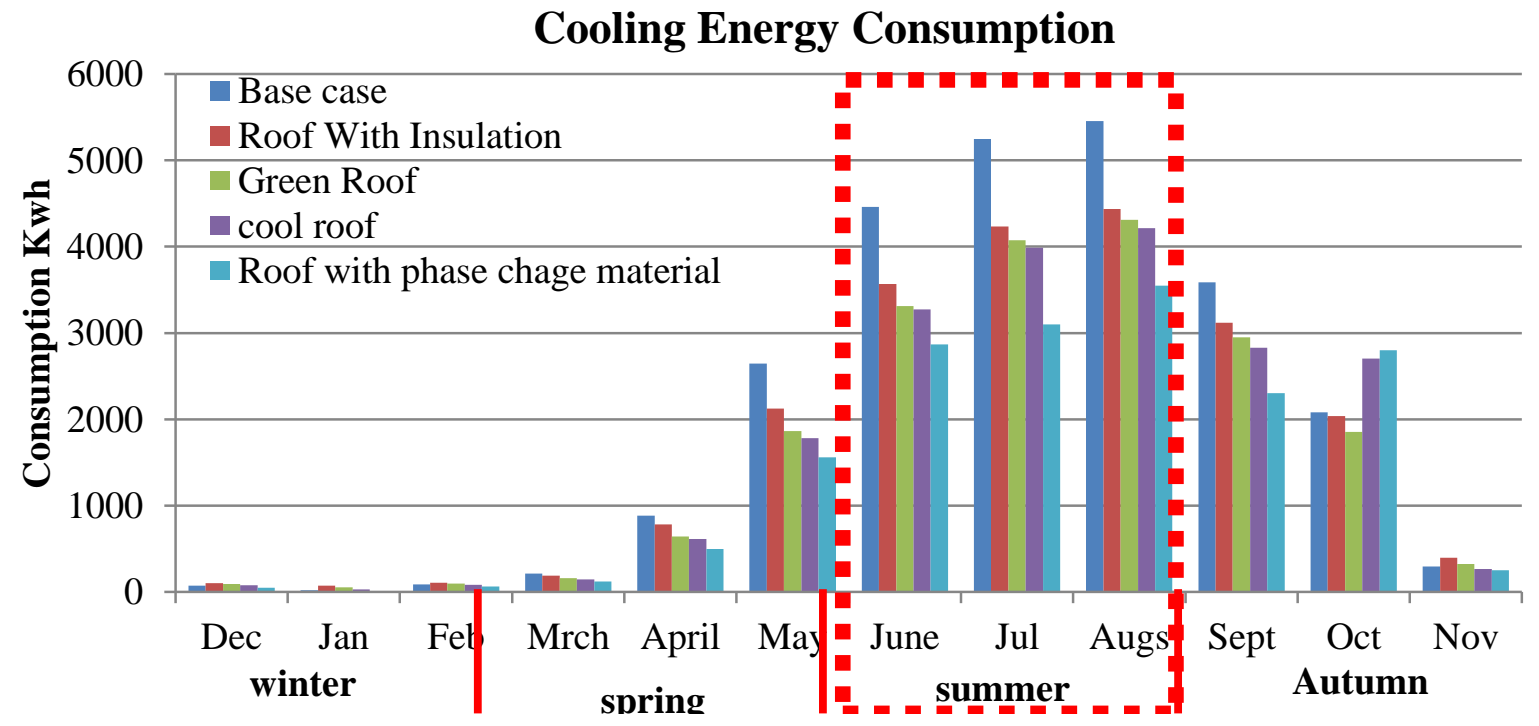

Figure 7 monthly cooling energy consumption Source: the researchers

Unlike cooling, energy consumption integrated roof with the phase change material is less effective in heating energy consumption when it is compared to other roof techniques (Roof with Insulation, Green Roof, and cool roof) in heating season. The heating energy saving when integrated roof with the phase change material is $6.4 \%$ compared with the base case, while $58.4 \%, 41.6 \%$ and $13.58 \%$ when adding insulation material, vegetation layer and cool material of total heating energy consumption per year respectively as shown in figure 8 . 


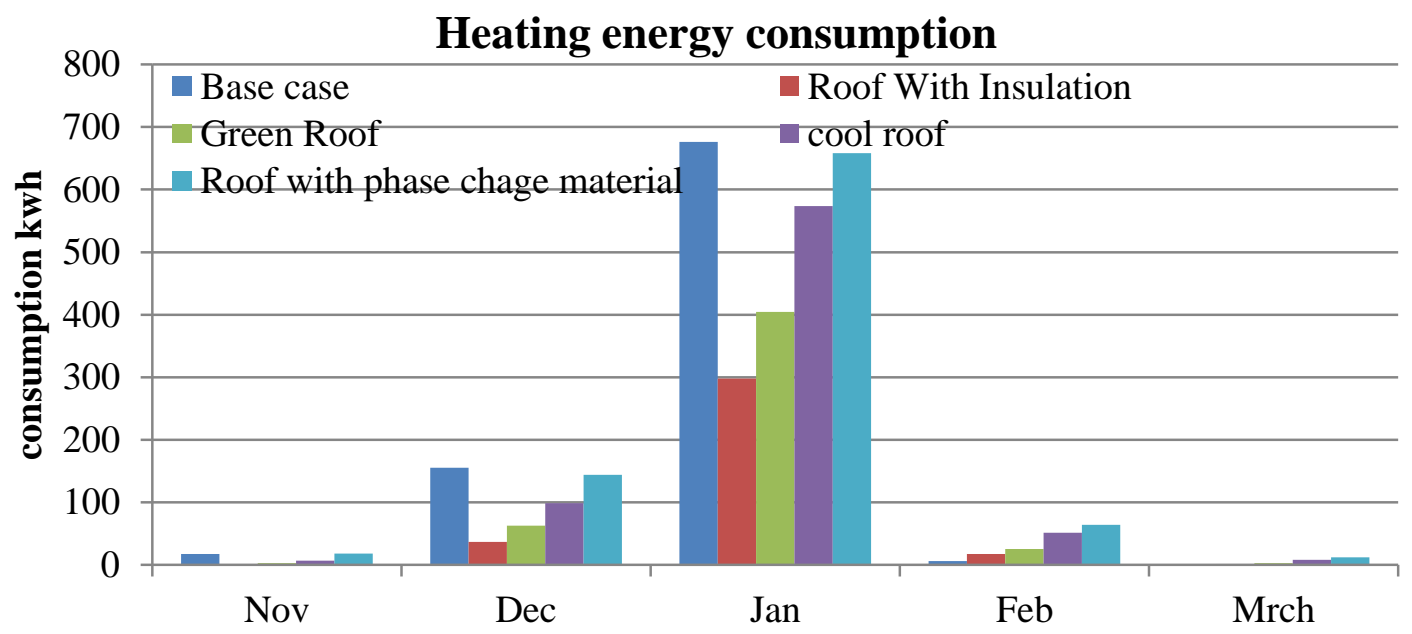

Figure 8 Heating energy consumption for different roof technique in winter period source : the researchers

The simulation shows that the total energy consumption per apartment (base case) is $25958 \mathrm{kwh}$ and maximum energy savings of about $30 \%$ when integrating PCM material with roof, while $24 \%, 22 \%$ and $17 \%$ by using cool material, vegetation layer and insulation material respectively compared with base case. The simulation shows also the potential savings are greater in the cooling season as shown in figure (9)

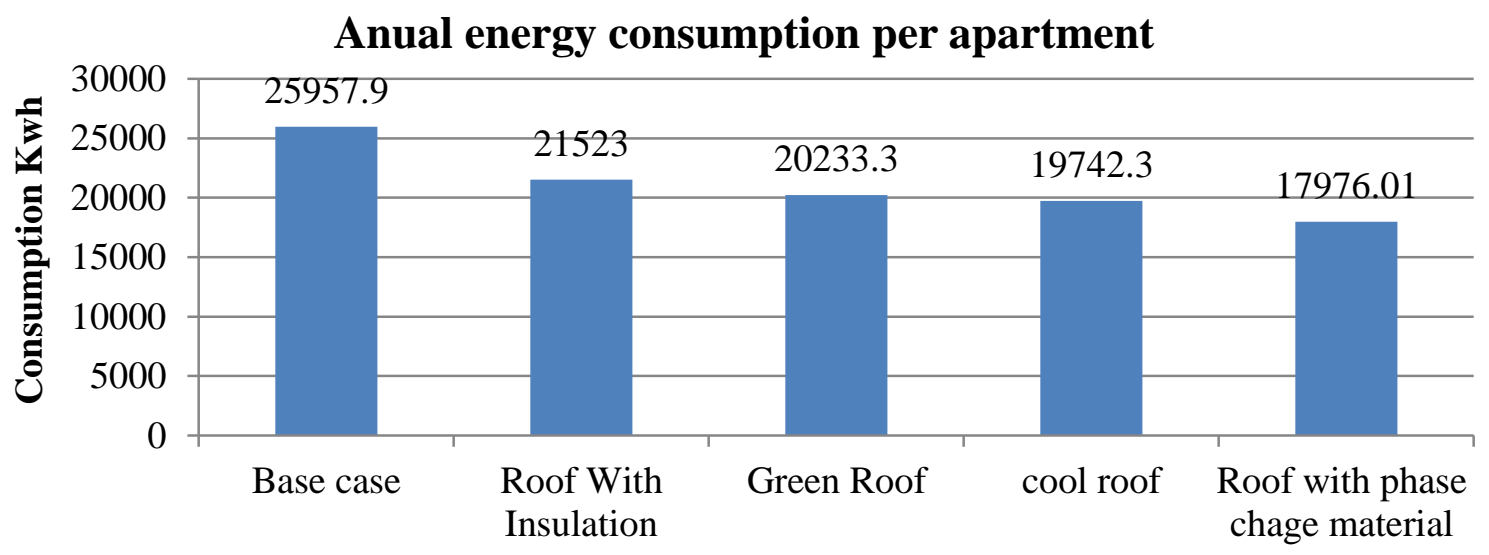

Figure 9 the impact of different roof technique on the total energy consumption source : the researchers

Figure 10 presents the results of using cool, PCM, isolated and green roofs in Cairo for whole building. The most efficient solution for the base case 
configuration is the roof with phase change material the total energy saving is around $12 \%$,slightly lower savings $(10 \%)$ are simulated for cool roof, while (9\%) saving energy when using green roof and $(7 \%)$ for roof with high effect thermal insulation, This saving for whole building but the results are maximized for the last floor which below the roof as shown in figure (10)

Total energy consumption for cooling and heating

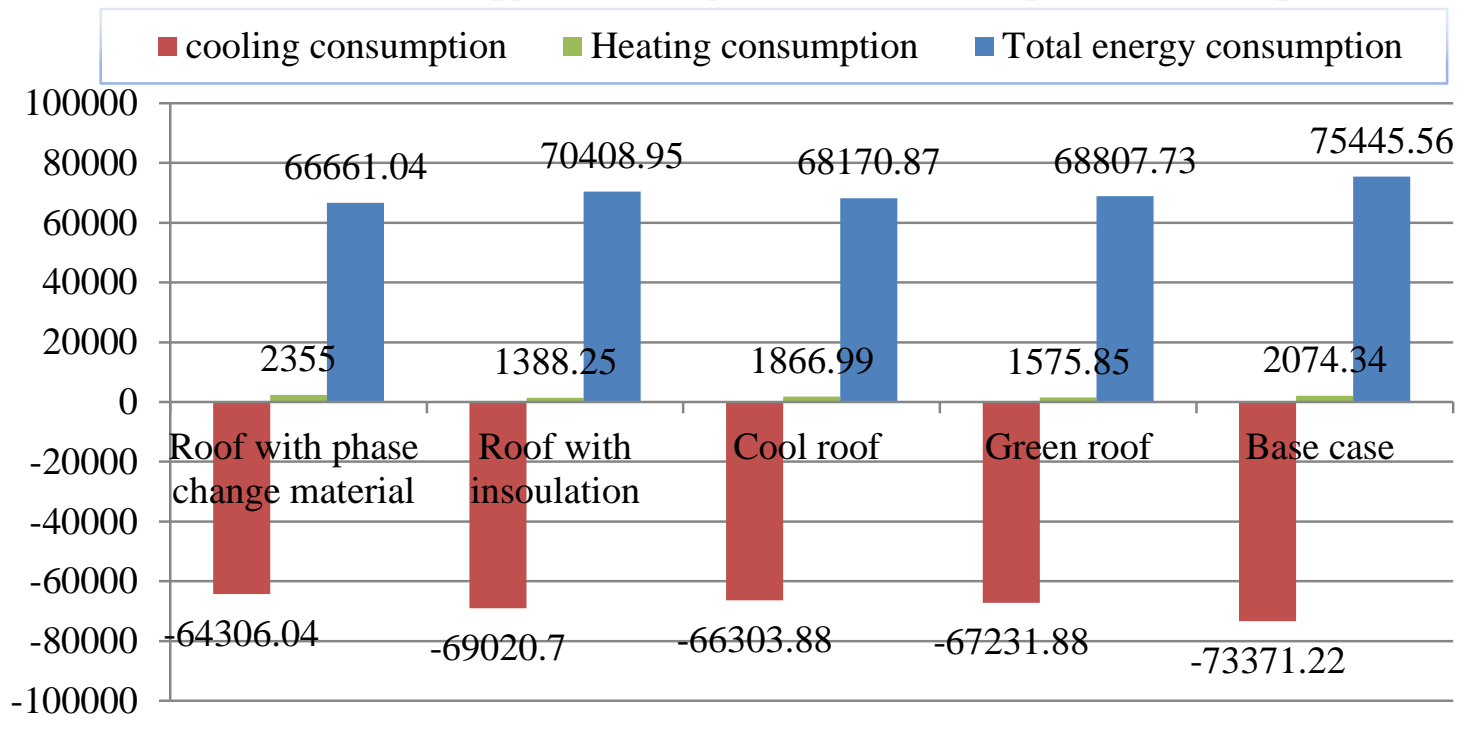

Figure 10 the impact of different roof technique on cooling and heating for building source : the researchers

\subsection{Thermal comfort}

The simulation shows that applying different roofs technique cool, PCM, isolated and green roofs achieve a big change in operative temperature that achieves better thermal comfort specially in summer periods as the temperature decreases around $6^{*} \mathrm{C}$ in summer season and slightly increases in winter season in operative temperature as shown in figure(11). 


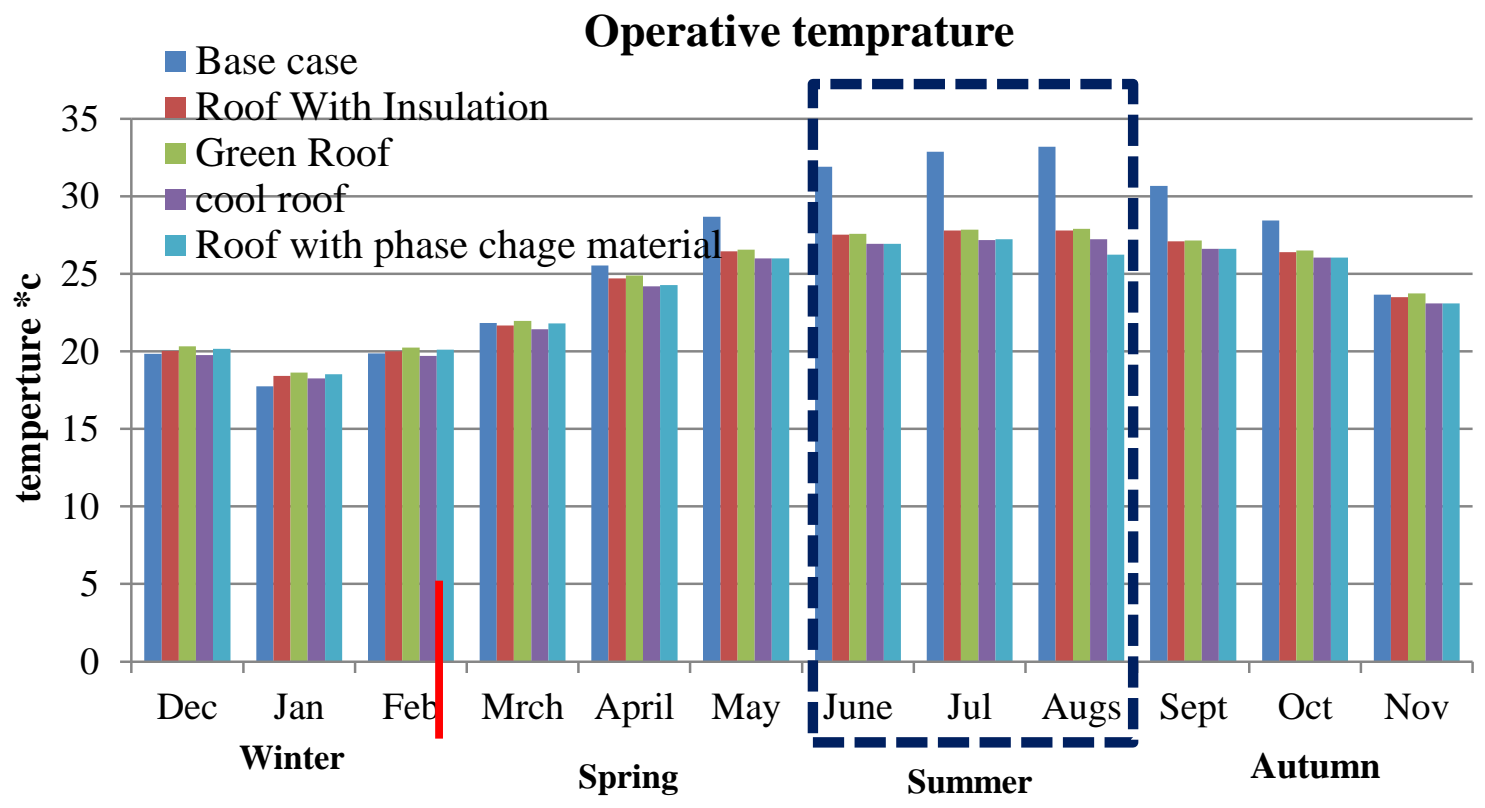

Figure11 the impact of different roof technique on Operative temprature source : the researchers

The discomfort hours are reduced to $14 \%$ respect to conventional roof when applying Green roof, Reductions around $10 \%$ and $12.5 \%$ are calculated for respectively Cool roof and roof with insulation material but when applying PCM on roof the discomfort hour reduction is around $5.5 \%$

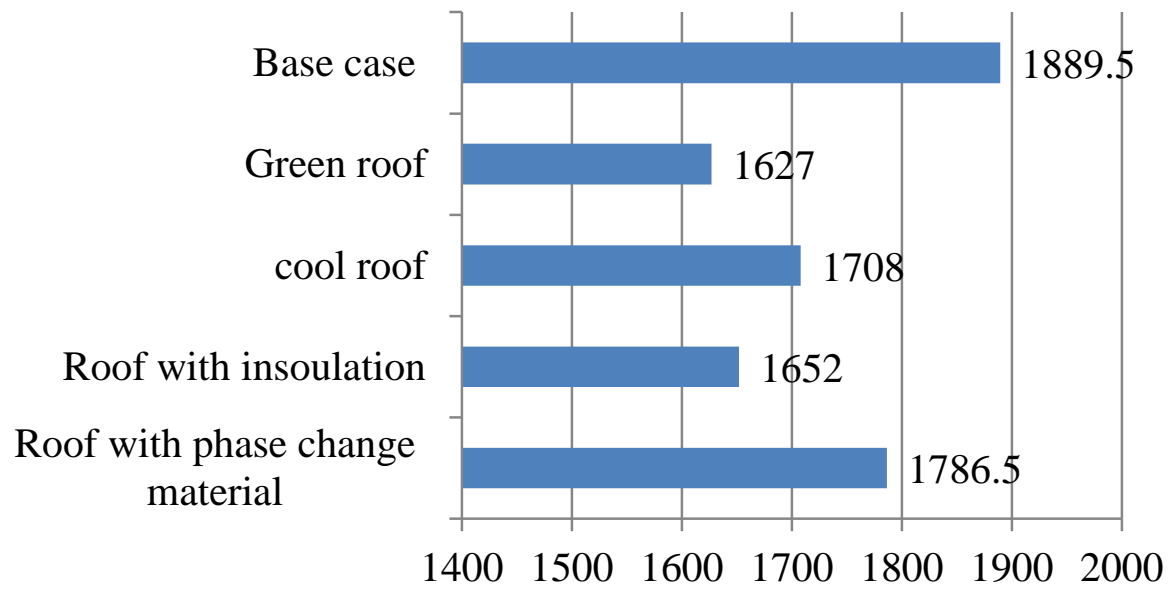

Figure 12 the impact of different roof technique on the discomfort hours source : the researchers

Relative humidity is associated with an inverse relationship with temperature. The higher relative humidity means lower the temperature. The Figure 13 shows that the relative humidity for the base case is higher than other roof solutions in the 
heating seasons and lower than other roof solutions in the cooling seasons. Accordingly, this technique has a good effect on thermal comfort.

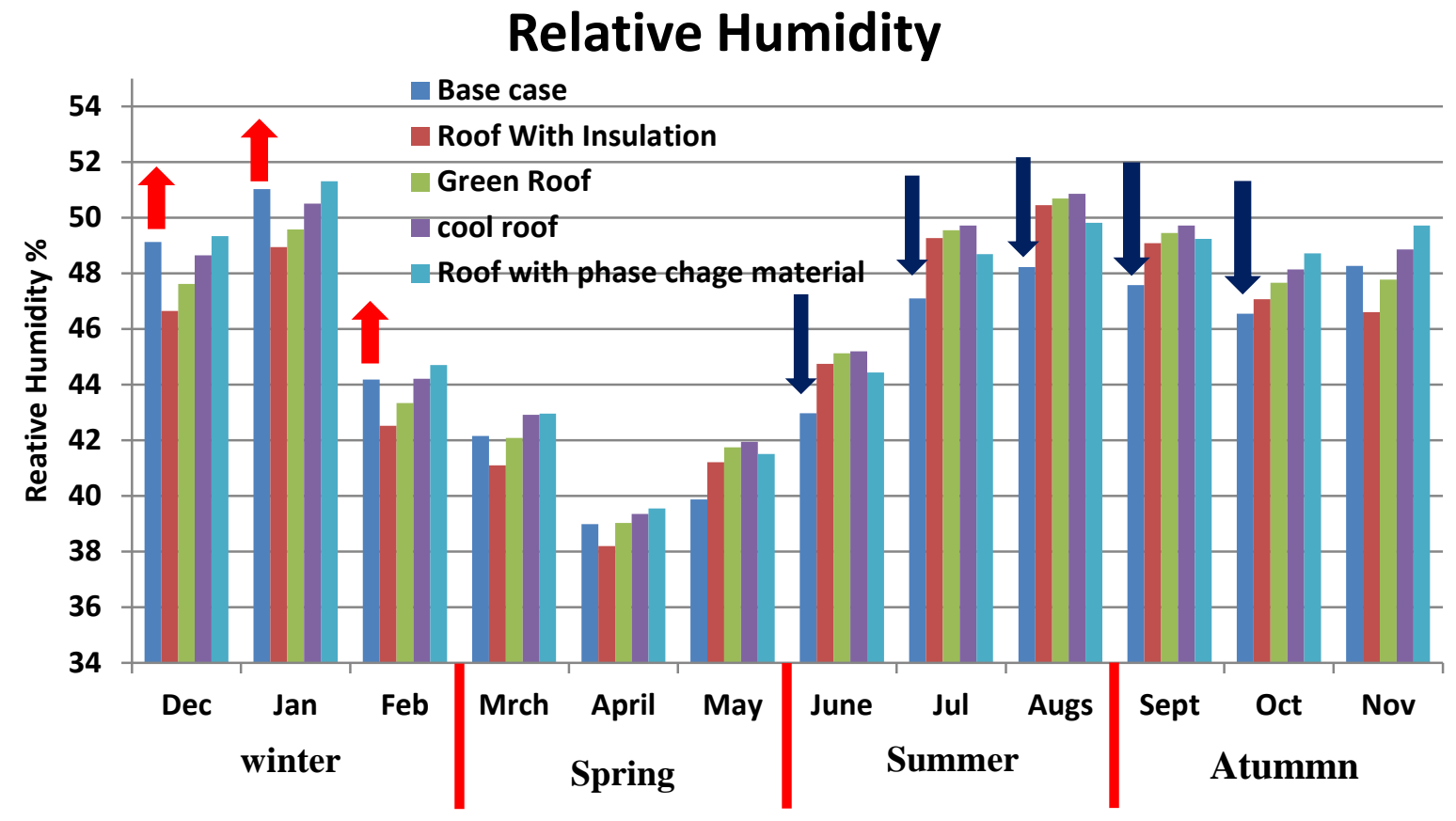

Figure 13 the impact of different roof technique onrelative humidity source : the researchers

\section{Conclusions}

This study has presented a comparison among different roofing techniques that are able to reduce the cooling demand of residential buildings in Egypt.

Roof with phase change material is the best solution for building envelop it is very effective for the cooling and energy savings when it is applied on the roof in residential buildings in Egypt, it can reduce electricity and enhance indoor comfort. as well when compared with the conventional roofs.

The case study showed that total yearly cooling energy consumed by the base case model around $25048.3 \mathrm{kWh}$ per annum, while roofs with insulation Roof, Green Roof, cool roof and Roof with phase change material have reduced the annual cooling energy consumption to $21168.67 \mathrm{kWh}, 19733.28 \mathrm{kWh}, 20003$ $\mathrm{kWh}$ and $17176 \mathrm{kWh}$, which mean the reduction around $15.4 \%, 21.21 \%, 20.14 \%$ and $31.4 \%$ respectively.

Indoor comfort simulation in this research founded that a building (base case) is very poor envelop that causes more energy consumption due to using more energy by air-conditioner. The Results also showed that the building with cool, PCM, isolated and green roofs reduced operative temperature around $5 \mathrm{c}, 5 \mathrm{c}$, 
5.5c, 5.6c in summer period respectively. Future researches could further focus on economic trade-offs when installing cool, PCM, isolated and green roofs in residential building in Egypt.

\section{References}

1. UNEP SBCI. "Buildings and Climate Change: Summary for DecisionMakers; United Nations Environmental Program", Sustainable Buildings and Climate Initiative: Paris, France, 2009.

2. Terés-Zubiaga, J.; Campos-Celador, A.; González-Pino, I.; Escudero-Revilla, C. "Energy and economic assessment of the envelope retrofitting in residential buildings in Northern Spain". Energy Build. 2015, Vol.86, PP.194-202. https://doi.org/10.1016/j.enbuild.2014.10.018.

3. S.Michel and H. Elsayed. Examples of flow energy design at urban scale in Egypt. PLEA, Switzerland, Geneva2006.

4. M. Aboulnaga, et al., "Sustainability of Higher Educational Buildings: Retrofitting approach to improve energy performance and mitigate $\mathrm{CO} 2$ emissions in hot climates", Energy Environ. Sustain. 2016. https://doi.org/10.1051/rees/2016016.

5. B. Basarir, et al., "Energy Efficient Retrofit Methods at the Building Envelopes of the School Buildings", Retrieved 10 12, 2016. , 2012.

6. Lawrence Berkley National Laboratory (LBNL). "Cool Roofs." 2000. http://eetd.lbl.gov/HeatIsland/CoolRoofs/

7. Levinson, R. \& Akbari, H. (2010). Potential benefits of cool roofs on commercial buildings: conserving energy, saving money, and reducing emission of greenhouse gases and air pollutants. Energy Efficiency, 3(1), 53109.

8. M.Kolokotroni, B.L. Gowreesunker, R.Giridharan,Cool roof technology in London : An experimental and modeling study, Energy and Buildings 67(2013) 658-667

9. Romeo, M. ZinziI,Impact of a cool roof application on the energy and comfort performance in an existing non-residential building. A Sicilian case study, Energy and Buildings 67 (2013) 647-657.

10.C. Romeo, M. ZinziI,Impact of a cool roof application on the energy and comfort performance in an existing non-residential building. A Sicilian case study, Energy and Buildings 67 (2013) 647-657. 
11.H. Akbari, S. Bretz, D. Kurn, H. Hartford, Peak power and cooling energy savings of high albedo roofs, Energy and Buildings 25 (1997) 117-126, H

12. A. Synnefa, M. Saliari, M. Santamouris, Experimental and numerical assessment of the impact of increased roof reflectance on a school building in Athens, Energy and Buildings 55 (2012) 7-15

13.E. Bozonnet, M. Doya, F. Allard, Cool roofs impact on building thermal response: A French case study, Energy and Buildings 43 (2011) 3006-3012.

14. C. Romeo, M. ZinziI,Impact of a cool roof application on the energy and comfort performance in an existing non-residential building. A Sicilian case study, Energy and Buildings 67 (2013) 647-657.

15. Ascione, F.; Bianco, N.; de' Rossi, F.; Turni, G.; Vanoli, G.P. "Green roofs in European climates. Are effective solutions for the energy savings in airconditioning". Appl. Energy 2013, Vol. 104, PP. 845-859. https://doi.org/10.1016/j.apenergy.2012.11.068.

16. Federal Energy Management Program (FEMP). "Green Roofs." DOE/EE0298. August 2004a.

17.C. Romeo, M. ZinziI,Impact of a cool roof application on the energy and comfort performance in an existing non-residential building. A Sicilian case study, Energy and Buildings 67 (2013) 647-657

18. Kamel, B.; Wahiba, S.; Nassar, K.; Abdelsalam, A. Effectiveness of green roof on reduction of energy consumption through simulation program for a residential building: Cairo, Egypt. In Proceedings of the Construction Research Congress, West Lafayette, Indiana, 21-23 May 2012. https://doi.org/10.1061/9780784412329.175.

19. S.S. Moody, D.J. Sailor, Development and application of a building energy performance metric for green roof, Energy Build. 2013, Vol. 60, PP. 262269. https://doi.org/10.1016/j.enbuild.2013.02.002.

20. I. Jaffal, S.-E. Ouldboukhitine, R. Belarbi, A comprehensive study of the impact of green roofs on building energy performance, Renewable Energy 43 (2012) 157-164.

21.H. Takebayashi, M. Moriyama, Surface heat budget on green roof and high reflection roof for mitigation of urban heat island, Building and Environment 42 (8) (2007) 2971-2979.

22.T. Theodosiou, Green roofs in buildings:thermal and environmental behaviour, Advances in Building Energy Research 3 (1) (2009) 271-288. 
23. Santamouris, M. (2014). Cooling the cities $-\mathrm{A}$ review of reflective and green roof mitigation technologies to fight heat island and improve comfort in urban environments. Solar Energy, 103(Supplement C), 682-7

24. Federal Energy Management Program (FEMP). "Green Roofs." DOE/EE0298. August 2004a.

25. Guichard, S.; Miranville, F.; Bigot, D.; Malet-Damour, B.; Libelle, T.; Boyer, H. Empirical Validation of a Thermal Model of a Complex Roof Including Phase Change Materials. Energies 2016, 9, 9.

26.. Voelker, C.; Kornadt, O.; Ostry, M. Temperature reduction due to the application of phase change materials. Energy Build. 2008, 40, 937-944.

27. Ozdenefe, M.; Dewsbury, J. Thermal performance of a typical residential Cyprus building with phase change materials. Build. Serv. Eng. Res. Technol. 2016, 37, 85-102

28. Solgi, E.; Fayaz, R.; Kari, B.M. Cooling load reduction in office buildings of hot-arid climate, combining phase change materials and night purge ventilation. Renew. Energy2016, 85, 725-731

29. Guichard, S.; Miranville, F.; Bigot, D.; Malet-Damour, B.; Libelle, T.; Boyer, H. Empirical Validation of a Thermal Model of a Complex Roof Including Phase Change Materials. Energies 2016

30. Jayalath, A.; Aye, L.; Mendis, P.; Ngo, T. Effect of phase change material roof layer on cooling and heating loads of a residential building in Melbourne and Sydney. Energy Build. 2016, 121, 152-158

31. Auzeby, M.; Wei, S.; Underwood, C.; Tindall, J.; Chen, C.; Ling, H.; Buswell, R. Effectiveness of using phase change materials on reducing summer overheating issues in UK residential buildings with identification of influential factors. Energies 2016

32. Y.P. Chun, W.J. Yu Yu, Influence of external thermal insulation compound system on the indoor temperature and humidity, Low Temperature Architecture Technology 2 (2004) 80-81.

33. A.A. Chowdhury, M.G. Rasul, M.M.K. Khan, Thermal-comfort analysis and simulation for various low-energy cooling-technologies applied to an office building in a subtropical climate, Applied Energy 85 (2008) 449-462

34. Al-HomoudM.S. (2005),-Performance characteristics and practical applications of common building thermal insulation materialsl, Building and Environment Volume 40, pp.353-366.I

35. S.Attia,A. Evrard, E. Gratia, Development of benchmark models for the Egyptian residential buildings sector, Appl. Energy 94 (2012) 270-284 